\title{
Reshaping the way we view vitamin $D$ signalling and the role of vitamin $D$ in health
}

\author{
James C. Fleet*, Jie Hong and Zhentao Zhang \\ Department of Foods and Nutrition and The Interdepartmental Nutrition Program, Purdue University, \\ West Lafayette, IN 47907-2059, USA
}

\begin{abstract}
Although the biological requirement for vitamin D can be met by epidermal exposure to UV light, there are a number of conditions where this production does not occur or is not sufficient to meet biological needs. When this happens, vitamin D must be consumed and is a nutrient. However, two distinct observations have caused researchers to rethink certain dogma in vitamin $\mathrm{D}$ biology. First, it appears that in addition to the hormonally active form of 1,25 dihydroxyvitamin $\mathrm{D}\left(1,25(\mathrm{OH})_{2} \mathrm{D}\right)$, circulating levels of 25 hydroxyvitamin $\mathrm{D}$ have a critical importance for optimal human health. This and other data suggest that extra-renal production of $1,25(\mathrm{OH})_{2} \mathrm{D}$ contributes to $\mathrm{Ca}$ homeostasis and cancer prevention. Second, in addition to its role in the transcriptional activation of genes through the vitamin $\mathrm{D}$ receptor there is now compelling evidence that $1,25(\mathrm{OH})_{2} \mathrm{D}$ has a second molecular mode of action; the rapid activation of second-messenger and kinase pathways. The purpose of this second mode of action is only now being explored. The present review will discuss how these two areas are reshaping our understanding of vitamin D metabolism and action.
\end{abstract}

Vitamin D: Calcium homeostasis: Cancer prevention: Cell signalling pathways

\section{Introduction: vitamin $D$ is a hormone and a nutrient}

Some 20 years ago, I (J.C.F.) remember sitting in a research seminar as a graduate student. Dr Hector DeLuca was the speaker and he was talking about his research on the mechanism of vitamin D action. Something he said at the outset of his seminar made a big impression on me and stuck deeply in my mind. He said, 'Vitamin D is a hormone and not a nutrient.' Perhaps he was overstating for effect. Still, I remember having the distinct feeling that he was shutting off a line of research for the nutrition community. However, we are now at a point where we can recognise both the truth and the limits of that statement.

It takes no stretch of the imagination to see that vitamin D works biologically as a steroid hormone. Like androgens and oestrogens, it has a cholesterol backbone. In addition, in response to various physiological signals, it can be metabolically activated (first in the liver, then in the kidney) and the active metabolite, 1,25 dihydroxyvitamin D $\left(1,25(\mathrm{OH})_{2} \mathrm{D}\right)$ acts as an endocrine signal on other tissues (for example, classically bone, intestine, and kidney) (Holick, 2003). Once in the target cell, 1,25(OH) $2 \mathrm{D}$ acti- vates a member of the steroid hormone receptor superfamily, the vitamin D receptor (VDR), and ligand activation of this receptor leads to the transcriptional activation of vitamin D-responsive genes (Haussler et al. 1998). This system is critically important for the modulation of $\mathrm{Ca}$ homeostasis and is exemplified by the adaptations that occur in response to changes in dietary $\mathrm{Ca}$ intake (Fig. 1).

Because vitamin D can be produced from 7-dehydrocholesterol in the skin, it is also understandable how the dietary intake of vitamin D came to be considered irrelevant. As long as the skin is regularly exposed to UV light in the 290 to $315 \mathrm{~nm}$ range (MacLaughlin et al. 1982), vitamin D status will be high and the vitamin $\mathrm{D}$ endocrine system will regulate $\mathrm{Ca}$ homeostasis. For example, for lifeguards in the middle of the summer, there is no nutritional requirement and vitamin $\mathrm{D}$ is best viewed as a hormone precursor produced in the skin. However, there is a growing recognition that many individuals and specific subgroups of the population do not make enough vitamin $\mathrm{D}$ in the skin to meet their physiological requirements (Holick, 2003). Low skin production of vitamin D (and low vitamin D status) occurs in the elderly and dark-skinned individuals (particularly if

\footnotetext{
Abbreviations: nVDR, nuclear vitamin D receptor; 25(OH)D, 25 hydroxyvitamin $\mathrm{D} ; 1,25(\mathrm{OH})_{2} \mathrm{D}, 1,25$ dihydroxyvitamin $\mathrm{D}$; PTH, parathyroid hormone; VDR, vitamin D receptor.

* Corresponding author: Dr James C. Fleet, fax +1 765494 0906, email fleetj@cfs.purdue.edu
} 


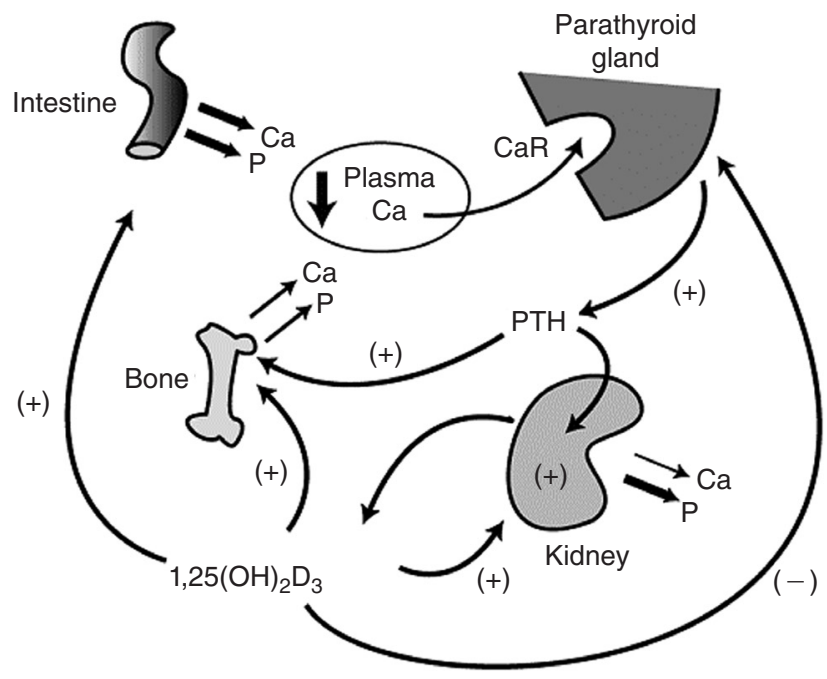

Fig. 1. Regulation of the vitamin D-parathyroid hormone (PTH) axis by dietary $\mathrm{Ca}$. In this scenario changes in dietary $\mathrm{Ca}$ intake are reflected as a change in serum ionised $\mathrm{Ca}$. These changes are detected by the Ca-sensing receptor $(\mathrm{CaR})$ and signal to the parathyroid gland that PTH production and release should increase (when dietary $\mathrm{Ca}$ and serum $\mathrm{Ca}$ are low) or decrease (when dietary $\mathrm{Ca}$ and serum $\mathrm{Ca}$ are high). PTH is a regulator of the renal $1 \alpha-$ hydroxylase that is responsible for increased production of 1,25 dihydroxyvitamin $\mathrm{D}_{3}\left(1,25(\mathrm{OH})_{2} \mathrm{D}_{3}\right)$. An increase in $\mathrm{PTH}$ and $1,25(\mathrm{OH})_{2} \mathrm{D}_{3}$ leads to increased bone resorption, reduced renal $\mathrm{Ca}$ and $\mathrm{P}$ excretion, and improved intestinal $\mathrm{Ca}$ and $\mathrm{P}$ absorption efficiency. Once produced in the kidney, $1,25(\mathrm{OH})_{2} \mathrm{D}_{3}$ is a strong negative regulator of PTH production. Under high dietary Ca these hormonal and physiological changes are reversed.

they are homebound), in individuals who use strong sunblocks in the summer and who avoid the sun, and individuals who live in the upper or lower parts of the northern or southern hemispheres during the winter. For these individuals, special efforts must be made to ensure vitamin D adequacy. This includes dietary supplementation.

\section{High 25 hydroxyvitamin D influences both calcium homeostasis and cancer risk}

While the preceding discussion highlights the nutritional importance of vitamin D, it implies that the biological importance of vitamin $\mathrm{D}$ depends upon an individuals ability to produce $1,25(\mathrm{OH})_{2} \mathrm{D}$ in the kidney and suggests that adequate health is dependent upon high circulating levels of that metabolite. This is intentional, as most of the science on the mechanism of vitamin $\mathrm{D}$ action points to $1,25(\mathrm{OH})_{2} \mathrm{D}$ as the critical active metabolite of vitamin $\mathrm{D}$. As Fig. 1 shows, the importance of increased renal $1,25(\mathrm{OH})_{2} \mathrm{D}$ production for maintaining $\mathrm{Ca}$ homeostasis can be clearly demonstrated under periods of low dietary Ca intake (Dawson-Hughes et al. 1993). Unfortunately, scientists who have attempted to correlate serum vitamin D metabolites to functional outcomes of $\mathrm{Ca}$ homeostasis do not always see a strong relationship between serum $1,25(\mathrm{OH})_{2} \mathrm{D}$ and these outcomes in apparently normal, healthy subjects. In fact several recent studies have shown that it is the serum level of 25 hydroxyvitamin $\mathrm{D}$ $(25(\mathrm{OH}) \mathrm{D})$, the precursor of $1,25(\mathrm{OH})_{2} \mathrm{D}$, that most closely correlates with several favourable outcomes for bone health. For example, although animal studies clearly demonstrate that $1,25(\mathrm{OH})_{2} \mathrm{D}$ is an important regulator of intestinal Ca absorption (Bronner et al. 1986; Song et al. $2003 b$ ), several studies have found that the efficiency of $\mathrm{Ca}$ absorption was positively correlated to serum $25(\mathrm{OH}) \mathrm{D}$ when levels vary within the normal range $(50 \cdot 1$ to $86 \cdot 5$ nmol/1) (Barger-Lux et al. 1995; Heaney et al. 1997, 2003; Devine et al. 2002). Similarly, even though $1,25(\mathrm{OH})_{2} \mathrm{D}$ is known to suppress parathyroid hormone (PTH) gene transcription (Demay et al. 1992), Thomas et al. (1998) and Chapuy et al. (1997) have shown that it is serum 25(OH)D levels that are associated with lower serum PTH levels (peak suppression at $80 \mathrm{nmol} / \mathrm{ml}$ ). This protection extends to protection from fractures; Trivedi et al. (2003) showed that the supplementation of elderly men and women with $2500 \mu \mathrm{g}(100000 \mathrm{IU})$ vitamin $\mathrm{D}_{3}$ every 4 months for 5 years significantly increased serum $25(\mathrm{OH}) \mathrm{D}$ and reduced the age-associated relative risk of fracture.

The importance of a high $25(\mathrm{OH}) \mathrm{D}$ status also appears to be important for a non-traditional action of vitamin $\mathrm{D}$ as well; cancer chemoprevention. Schwartz \& Hulka (1990) hypothesised that vitamin D deficiency is the underlying factor for increased prostate cancer risk due to advancing age, Black race, and northern latitudes; factors associated with decreased synthesis of vitamin D in the skin (Holick, 1997). This group later confirmed that low prostate cancer rates were associated with high UV radiation exposure in the USA (Hanchette \& Schwartz, 1992). Several groups have attempted to establish a direct relationship between high vitamin D status and prostate cancer risk. For example, Ahonen et al. (2000) found a $70 \%$ increased prostate cancer risk in men with $25(\mathrm{OH}) \mathrm{D}$ levels below the median, especially in younger men $(<52$ years) who entered the study with low serum 25(OH)D (adjusted odds ratio 3.5).

\section{How does a high serum 25 hydroxyvitamin D level offer protection?}

The observations regarding 25(OH)D-mediated effects on bone and cancer endpoints might be explained in a number of ways. First, they might be artefacts of the simple fact that $1,25(\mathrm{OH})_{2} \mathrm{D}$ is unstable and that it is hard to measure long-term exposure to this metabolite. The half-life of $25(\mathrm{OH}) \mathrm{D}$ in the serum is about 2 weeks, whereas the halflife of $1,25(\mathrm{OH})_{2} \mathrm{D}$ is less than $6 \mathrm{~h}$ (Haddad \& Rojanasathit, 1976; Mason et al. 1980). As a result, a peak in serum $1,25(\mathrm{OH})_{2} \mathrm{D}$ could initiate a change in intestinal Ca absorption but that peak could be gone by the time intestinal $\mathrm{Ca}$ absorption is elevated (i.e. reducing the correlation between the two parameters). Another possibility is that high levels of $25(\mathrm{OH}) \mathrm{D}$ may bind directly to the VDR leading to activation of gene transcription. Brumbaugh \& Haussler (1973) have shown that even though $25(\mathrm{OH}) \mathrm{D}$ has a low affinity for the VDR (500-1000-fold lower affinity than $\left.1,25(\mathrm{OH})_{2} \mathrm{D}\right)$, high levels of $25(\mathrm{OH}) \mathrm{D}$ can displace $1,25(\mathrm{OH})_{2} \mathrm{D}$ from the receptor. Based upon this hypothesis, $25(\mathrm{OH}) \mathrm{D}$, whose serum levels are 1000 times greater than serum $1,25(\mathrm{OH})_{2} \mathrm{D}$ levels, may be a direct, physiologically 
relevant activator of gene transcription through activation of the VDR. While this hypothesis fails to take into account the impact of the serum vitamin D-binding protein (i.e. $25(\mathrm{OH}) \mathrm{D}$ has $>600$-fold higher affinity and thus may be less likely to be transferred to tissues), this effect certainly accounts for the ability of vitamin D and 25(OH)D to reverse the phenotype of genetic pseudovitamin D-deficient rickets caused by mutations in the $1 \alpha$-hydroxylase gene (Glorieux \& St-Arnaud, 1997). Still, massive amounts of vitamin D (>20 $000 \mathrm{IU}$ or $500 \mu \mathrm{g} / \mathrm{d})$ and $25(\mathrm{OH}) \mathrm{D}(>100$ $\mu \mathrm{g} / \mathrm{d})$ are needed for this effect. This makes it improbable that the relatively moderate increases in $25(\mathrm{OH}) \mathrm{D}$ that suppress PTH or provide protection against cancer are working through this pathway (i.e. 2-3-fold changes).

\section{Extra-renal production of 1,25 dihydroxyvitamin $D$ is critical for optimal health}

A final hypothesis to explain the beneficial effects of high serum $25(\mathrm{OH}) \mathrm{D}$ levels is that there may be local production of $1,25(\mathrm{OH})_{2} \mathrm{D}$ in a wide variety of tissues, i.e. $1,25(\mathrm{OH})_{2} \mathrm{D}$ is working as an autocrine or a paracrine regulator rather than an endocrine regulator. Although textbooks teach that the production of $1,25(\mathrm{OH})_{2} \mathrm{D}$ is exclusively renal, there has been evidence to support extra-renal production for some time. Dusso et al. (1988) and Jongen et al. (1984) both found that supplementing anephric subjects with $25(\mathrm{OH}) \mathrm{D}$ increased serum $1,25(\mathrm{OH})_{2} \mathrm{D}$ levels from very low levels to low normal ranges. Consistent with these observations, Zehnder et al. (2001) found extra-renal expression of the $1 \alpha$-hydroxylase protein by immunohistochemistry in skin, lymph nodes, pancreatic islets, brain, placenta, and in colonic epithelial cells.

Recently, several papers have provided data that support a role for the local production of $1,25(\mathrm{OH})_{2} \mathrm{D}$ in prostate cancer prevention. Hsu et al. (2001) examined eighteen cell lines of normal prostatic epithelial cells, eight cell lines of cells from patients with benign prostatic hypertrophy cells, fifteen adenocarcinoma cell lines, and four established prostate cancer cell lines (LNCaP, PC-3, DU145 and MDAPCa 2b). They found that normal prostate epithelial cells displayed a high level of $1 \alpha$-hydroxylase activity $(2 \cdot 20 \pm$ $0.61 \mathrm{pmol} / \mathrm{mg}$ protein per $\mathrm{h}$ ). This activity was impaired in benign prostatic hypertrophy cells $(1 \cdot 48 \pm 0 \cdot 18 \mathrm{pmol} / \mathrm{mg}$ protein per $\mathrm{h})$, primary cultures of prostate cancer cells $(0 \cdot 32$ $\pm 0.15 \mathrm{pmol} / \mathrm{mg}$ protein per h) and prostate cancer cell lines $(0 \cdot 17 \pm 0 \cdot 16 \mathrm{pmol} / \mathrm{mg}$ protein per $\mathrm{h})$. They subsequently showed that the percentage of growth inhibition in response to treatment of cells with $25(\mathrm{OH}) \mathrm{D}$ was dependent upon the $1 \alpha$-hydroxylase activity. As a result, while the prostate cancer cell line $\mathrm{LNCaP}$ was responsive to $1,25(\mathrm{OH})_{2} \mathrm{D}$ treatment, their lack of $1 \alpha$-hydroxylase activity caused them to be unresponsive to $25(\mathrm{OH}) \mathrm{D}$ treatment. Whitlatch et al. (2002) later demonstrated that the anti-proliferative effects of $25(\mathrm{OH}) \mathrm{D}_{3}$ could be restored in LNCaP cells transfected with a transgene conferring $1 \alpha$-hydroxylase activity.

These data provide strong support for the role of autocrine or paracrine regulation in prostate cancer prevention. This model has been generalised, integrated with the more traditional renal mode of $1,25(\mathrm{OH})_{2} \mathrm{D}$ production, and is presented in Fig. 2. Still, it must be noted that there has not yet been a report of $1 \alpha$-hydroxylase expression in the vitamin D-responsive, Ca-transporting cells of the small intestine. Similarly, it has not been demonstrated that the loss of $1 \alpha$-hydroxylase activity in the prostate leads to increased prostate cancer or that the loss in the intestine leads to reduced efficiency of intestinal $\mathrm{Ca}$ absorption. With the development of global and conditional $1 \alpha$-hydroxylase knockout mice (St Arnaud et al. 2003), the ability to test these questions directly (as well as the quantitative assessment of $25(\mathrm{OH}) \mathrm{D}$ as a direct activator of the VDR) is within reach.

\section{The two modes of 1,25 dihydroxyvitamin D action}

The bulk of the research on $1,25(\mathrm{OH})_{2} \mathrm{D}$ action has focused on the activation or repression of gene transcription that is mediated through the VDR. This and other data comprise a significant body of evidence supporting a critical role for the VDR in the Ca-regulating actions of $1,25(\mathrm{OH})_{2} \mathrm{D}$ (see Fig. 3 for a current model of the mechanism of vitamin Dmediated gene activation). For example, mutations in the VDR cause genetic rickets (vitamin D-resistant rickets or type II rickets) and alopecia in affected individuals. Also, serum PTH levels are dramatically elevated and intestinal $\mathrm{Ca}$ absorption is lower in nuclear VDR (nVDR) knockout mice compared with wild-type littermates (van Cromphaut

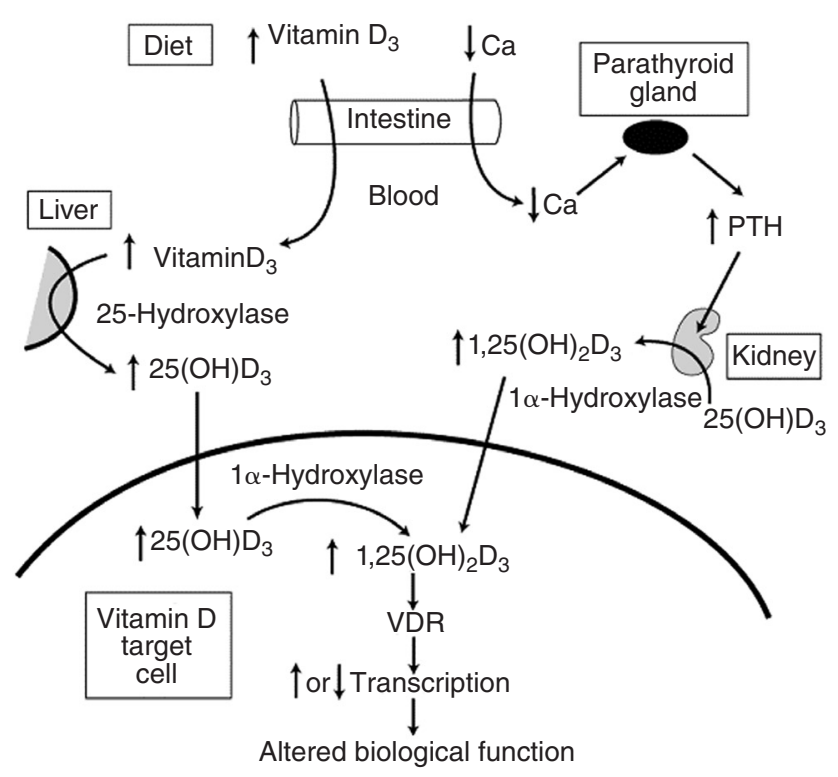

Fig. 2. Model for local production and autocrine action of 1,25 dihydroxyvitamin $\mathrm{D}_{3}\left(1,25(\mathrm{OH})_{2} \mathrm{D}_{3}\right)$. Traditionally, consumption of a low-Ca diet leads to increased renal production of $1,25(\mathrm{OH})_{2} \mathrm{D}_{3}$ and endocrine signalling leading to activation of the vitamin $D$ receptor (VDR)-mediated gene transcription in vitamin D target tissues (for additional details, see Fig. 1). Alternately, the presence of extrarenal $1 \alpha$-hydroxylase activity in several non-traditional vitamin $D$ target tissues suggests that autocrine signalling may occur within cells due to elevated serum 25 hydroxyvitamin $D_{3}\left(25(O H) D_{3}\right)$ levels that result from feeding a diet with high dietary vitamin $\mathrm{D}$ content or after high exposure to UV light in the proper wavelength. Although not shown, locally produced $1,25(\mathrm{OH})_{2} \mathrm{D}_{3}$ could also be released and act locally as a paracrine signal. PTH, parathyroid hormone. 


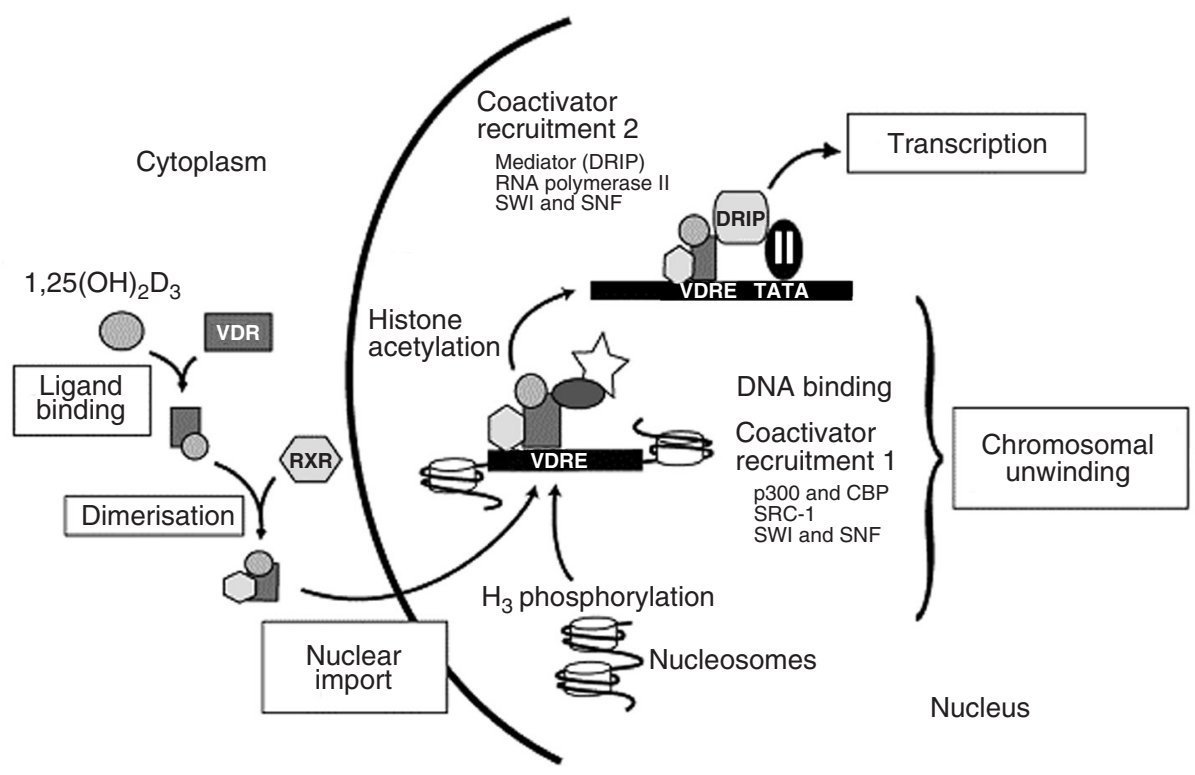

Fig. 3. Regulation of gene transcription through the nuclear vitamin $D$ receptor (VDR). This figure is a summary of our current knowledge regarding vitamin $\mathrm{D}$-activated gene transcription. The process requires multiple steps that are initiated by ligand binding to the VDR, i.e. dimerisation of VDR to the retinoid X receptor (RXR), nuclear import of the VDR-RXR complex, co-activator-mediated chromosomal unwinding, and co-activator-mediated activation of the basal transcription unit containing RNA polymerase II. DRIP, mediator D complex; SWI and SNF, ATP-dependent chromatin remodelling complex; VDRE, vitamin D response element; TATA, binding site in gene promoters for RNA polymerase II; CBP, cAMP-response element-binding protein-binding protein; SRC-1, steroid receptor co-activator-1.

et al. 2001; Song et al. 2003a). The VDR is also critical for the growth-inhibitory properties of $1,25(\mathrm{OH})_{2} \mathrm{D}$; prostate cancer cells with little or no VDR are not growth inhibited in response to $1,25(\mathrm{OH})_{2} \mathrm{D}$ treatment (Miller et al. 1995; Hedlund et al. 1996a,b; Zhuang et al. 1997).

While research on VDR-mediated gene transcription continues to be fruitful, there is now compelling evidence for the existence of rapid activation of signal-transduction pathways by $1,25(\mathrm{OH})_{2} \mathrm{D}$ within various cell types (Nemere \& Farach-Carson, 1998; Sitrin et al. 1999). Fig. 4 summarises the kinase and second-messenger pathways that have been shown to be activated through rapid $1,25(\mathrm{OH})_{2} \mathrm{D}$-mediated signalling. This form of signalling has been more closely associated with the mechanism of action of peptide hormones and growth factors yet is being recognised as important for the action of other steroid hormones as well (Harvey et al. 2002). Nonetheless, the discovery of a second mechanism for vitamin $\mathrm{D}$ action raises several interesting questions: i.e. 'why do we need two distinct vitamin D signalling pathways?', 'are there independent biological processes regulated by each pathway?', and 'how does vitamin D signal the cell to rapidly initiate signal-transduction pathways?'

While the recent observations on rapid $1,25(\mathrm{OH})_{2} \mathrm{D}$ signalling are interesting, the central importance of VDRmediated signalling appears to leave little room for an independent effect of these pathways. To date, the area that best demonstrates the importance of the rapid activation of kinase pathways by $1,25(\mathrm{OH})_{2} \mathrm{D}$ is the modulation of growth-zone chondrocyte biology (Boyan et al. 1994, 1999, 2003). Treatment of growth-zone chondrocytes with $1,25(\mathrm{OH})_{2} \mathrm{D}$ activates phospholipase $\mathrm{A}_{2}$ and causes an increase in membrane fluidity, activates phospholipase $\mathrm{C}$ leading to the activation of protein kinase $\mathrm{C}$ and release of intracellular $\mathrm{Ca}$, and indirectly activates protein kinase $\mathrm{A}$ through production of prostaglandin $\mathrm{E}_{2}$. These changes are important for the activation of growth factors (i.e. latent transcriptional growth factor- $\beta$ in matrix), proteoglycan degradation, and matrix mineralisation. The fact that these effects occur in the nucleus-free matrix vesicles released from chondrocytes, as well as in intact chondrocytes, clearly demonstrates that the events are independent of transcriptional activation. The final aspect of this system that bears noting is that chondrocytes have the ability to produce $1,25(\mathrm{OH})_{2} \mathrm{D}$ from $25(\mathrm{OH}) \mathrm{D}$ (Schwartz et al. 1992). This is consistent with the idea of an autocrine or paracrine signalling pathway that was developed in the first part of the present review.

\section{Do rapid and nuclear 1,25 dihydroxyvitamin D signalling pathways interact?}

It is not essential that rapid vitamin D signalling be independent of the VDR or VDR-mediated gene activation. In fact, there are two lines of evidence that suggest the rapid activation of kinases by $1,25(\mathrm{OH})_{2} \mathrm{D}$ and the function of the VDR are related. A model for these interactions is presented in Fig. 5.

Modulation of vitamin $D$ receptor function by kinase activation. Several studies support the hypothesis that signal-transduction pathways are important regulators of nVDR-mediated gene expression. For example, the 


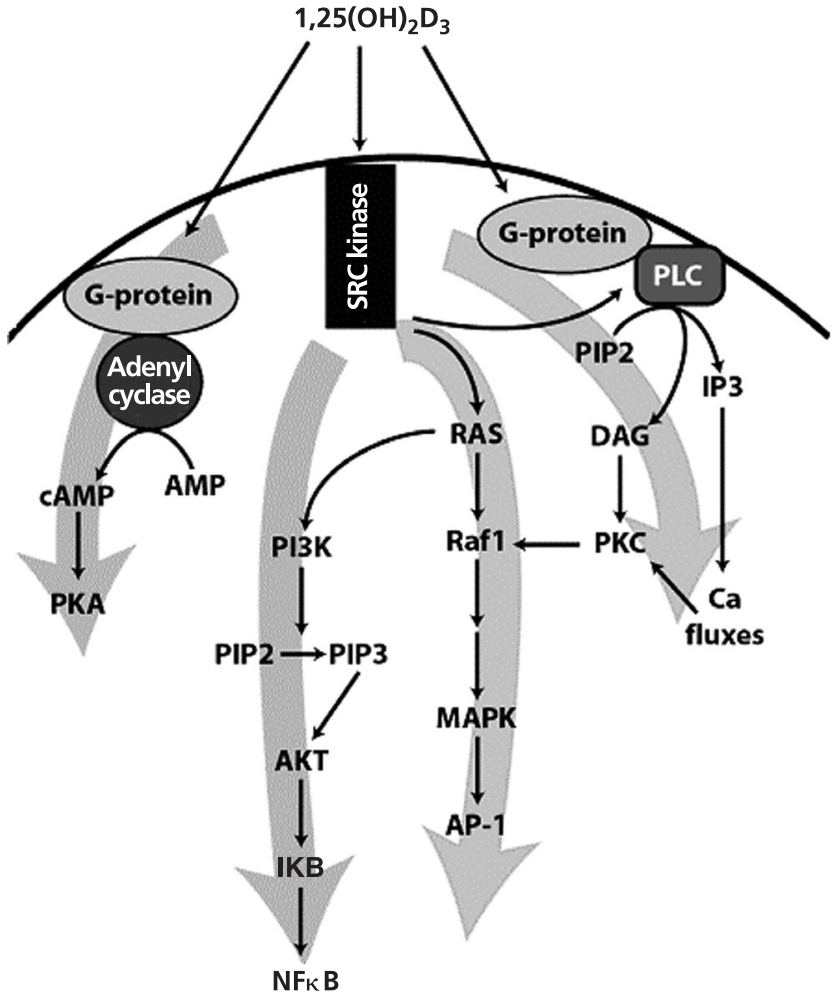

Fig. 4. Rapid activation of signal-transduction pathways by 1,25 dihydroxyvitamin $D_{3}\left(1,25(\mathrm{OH})_{2} D_{3}\right)$. Recent evidence indicates that in addition to the classical mode of action utilising the vitamin $\mathrm{D}$ receptor (see Fig. 3), $1,25(\mathrm{OH})_{2} \mathrm{D}_{3}$ can rapidly activate various kinase and second-messenger pathways: protein kinase $A$ (PKA), $\mathrm{NF}-\kappa \mathrm{B}$, mitogen-activated protein kinases (MAPK), and protein kinase $C$ (PKC). Please note that not all of the pathways listed have been described in all cell types. SRC, receptor tyrosine kinase; P13K, phosphatidylinositol 3 kinase; PIP2, phosphatidylinositol-4,5 bisphosphate; PIP3, phosphatidylinositol-3,4,5 trispohosphate; AKT, protein kinase $\mathrm{B}$; IKB, inhibitor of $\mathrm{NF} K \mathrm{~B}$; Raf1, mitogen activated kinase kinase kinase; AP, activated protein; PLC, phospholipase C; DAG, diacylglycerol; IP3, inositol triphosphate.

suppression of protein kinase $\mathrm{C}$ activity with staurosporine or $\mathrm{H} 7$ inhibited $1,25(\mathrm{OH})_{2} \mathrm{D}$-regulated 25-hydroxyvitamin D 24-hydroxylase (CYP24) gene expression in proliferating, small-intestine crypt-like, rat IEC-6 cells (Koyama et al. 1994) and the activation of protein kinase $C$ with phorbol esters enhanced 1,25(OH) 2 -regulated CYP24 gene transcription in IEC-6 and IEC-18 cells (Armbrecht et al. 2001). Similar findings have been observed for $1,25(\mathrm{OH})_{2} \mathrm{D}$-mediated osteocalcin gene expression in the osteoblast-like ROS 17/2.8 cell (Desai et al. 1995), CYP24 gene induction in COS-1 cells (Dwivedi et al. 2002), c-myc activation in proliferating skeletal muscle (Buitrago et al. 2001a) and CYP3A4 gene regulation in proliferating Caco2 cells (Hara et al. 2002). Specific cross-talk between rapid, membrane-initiated vitamin D actions and nVDR-mediated genomic actions are also supported by the observation that an antagonist of the non-genomic pathway, $1 \beta, 25(\mathrm{OH})_{2} \mathrm{D}$, blocks $1 \alpha, 25(\mathrm{OH})_{2} \mathrm{D}$-mediated osteocalcin gene transcription in osteoblasts (Baran et al. 1992).

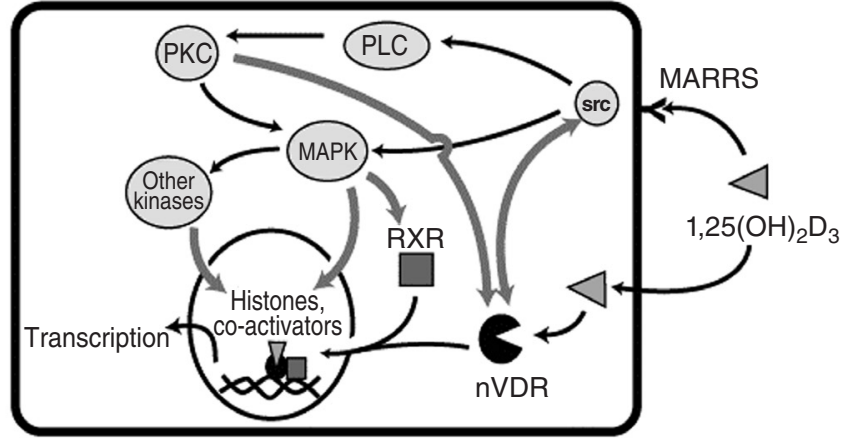

Fig. 5. A model of cross-talk between 1,25 dihydroxyvitamin $D_{3}$ $\left(1,25(\mathrm{OH})_{2} \mathrm{D}_{3}\right)$ signalling pathways. The model here depicts simplified versions of the classical vitamin $D$ receptor (VDR)mediated transcriptional activation pathway and the rapid activation of kinases by $1,25(\mathrm{OH})_{2} \mathrm{D}_{3}$. The larger, grey arrows indicate potential points of cross-talk between the two pathways that are supported by the literature. This cross-talk includes a role of kinase pathways in modulating the transcriptional activity of the VDR as well as a non-transcriptional role for the VDR in transducing the signal to initiate kinase activity. PKC, protein kinase C; PLC, phospholipase C; src, receptor tyrosine kinase; MARRS, membrane-associated rapid response steroid-binding protein; MAPK, mitogen-activated protein kinase; RXR, retinoid X receptor; nVDR, nuclear VDR.

The mechanism for this interaction between $1,25(\mathrm{OH})_{2} \mathrm{D}$-induced kinase pathways and VDR-mediated gene transcription is unclear but is probably due to the modulation of protein-protein interactions that are responsible for the recruitment of co-activators necessary for the disruption of higher-order chromatin structure and transcriptional activation (see Fig. 3). For example, Paredes et al. (2002) showed that access to vitamin D response elements in the osteocalcin gene promoter is limited when the DNA is present in a chromosomal context. As a result, protein-protein interactions mediated by the nVDR are critical for chromosomal unwinding. That is, before transcriptional activation, the $\mathrm{nVDR}$-retinoid $\mathrm{X}$ receptor dimer recruits cAMP-response element-binding protein-binding protein and steroid receptor co-activator- 1 to make a complex with histone acetyl transferase activity that acetylates histones $\mathrm{H}_{3}$ and $\mathrm{H}_{4}$ and relieves the constraints imposed by chromatin structure (Chen et al. 1999; Freedman, 1999). Both cAMP-response element-binding protein-binding protein and steroid receptor co-activator-1 are targets of mitogenactivated protein kinase-mediated phosphorylation and this may lead to increased histone acetyl transferase activity of the complex (Rowan et al. 2000; Lee et al. 2003). In addition, after chromosomal unwinding, the nVDR-retinoid $\mathrm{X}$ receptor dimer recruits the mediator $\mathrm{D}$ complex (also known as DRIP) and utilises it to recruit and activate the basal transcription unit containing RNA polymerase II (Rachez et al. 1999; Chiba et al. 2000). Barletta et al. (2002) showed that the association between the nVDR and a member of the mediator complex, DRIP205, was enhanced following the treatment of cultured bone and kidney cells with the phosphatase inhibitor okadaic acid. This interaction enhanced $1,25(\mathrm{OH})_{2} \mathrm{D}$-mediated reporter gene 
activity. These and other data suggest that $1,25(\mathrm{OH})_{2} \mathrm{D}$ mediated activation of various kinase pathways could lead to the phosphorylation of critical co-activators and this in turn could increase the transcriptional activation of vitamin $\mathrm{D}$ target genes by increasing VDR co-activator interactions. However, while this suggests that cross-talk between the two vitamin D signal pathways exists, more work is needed to solidify the connections between the rapid actions of $1,25(\mathrm{OH})_{2} \mathrm{D}$ and the classical activation of the VDR by $1,25(\mathrm{OH})_{2} \mathrm{D}$.

Involvement of vitamin $D$ receptor in the rapid activation of signal-transduction pathways. There is considerable controversy regarding the mechanism used by $1,25(\mathrm{OH})_{2} \mathrm{D}$ to transduce a signal across the membrane of cells and activate kinase pathways. One line of evidence suggests that there may be a unique membrane receptor for $1,25(\mathrm{OH})_{2} \mathrm{D}$. This protein has been termed the membrane-associated rapid response steroid-binding protein (Farach-Carson \& Nemere, 2003). This protein binds $1,25(\mathrm{OH})_{2} \mathrm{D}$ with high affinity, is distinct from the classical VDR, and is found on the membrane of a number of cells that respond to $1,25(\mathrm{OH})_{2} \mathrm{D}$ treatment by activating kinase pathways and stimulating $\mathrm{Ca}$ fluxes. However, in addition to this protein, several recent papers have indicated that the classical VDR may be involved in at least some of the rapid $1,25(\mathrm{OH})_{2} \mathrm{D}$ signalling pathways.

Buitrago et al. $(2000,2001 b)$ have demonstrated that in myocytes $1,25(\mathrm{OH})_{2} \mathrm{D}$ treatment activates the membraneassociated tyrosine kinase, src kinase, and this coincides with an increased association of VDR with src kinase as well as tyrosine phosphorylation of the VDR, i.e. the VDR is a target of src kinase activation. Bettoun et al. (2003) found that in Caco-2 cells VDR is part of a terniary complex with the protein phosphatase PP1c and the p70 S6 kinase that is known to control the movement of cells through the G1-S transition in the cell cycle (Bettoun et al. $2003)$. Treatment of cells with $1,25(\mathrm{OH})_{2} \mathrm{D}$ resulted in the PP1c-mediated dephosphorylation and inactivation of $\mathrm{p} 70$ S6 kinase. This indicates that rapid signalling requiring the VDR in a non-traditional role can lead to the growth arrest of proliferating Caco- 2 cells in part through the inactivation of p70 S6 kinase. Finally, Erben et al. (2002) found that the $1,25(\mathrm{OH})_{2} \mathrm{D}$-mediated activation of $\mathrm{Ca}$ fluxes is blocked in osteoblasts from mice expressing a nVDR that lacks the DNA-binding domain. Although this observation conflicts with data generated by Wali et al. (2003) in VDR-null mice, coupled with the other data from cell systems, it suggests that the VDR may participate in at least some rapid signalling pathways.

\section{Summary and conclusions}

The purpose of the present review was to demonstrate that certain dogma that has been used to explain the biology of vitamin $\mathrm{D}$ action is falling under question. In the first part of the review, we discussed how in some circumstances the circulating level of $25(\mathrm{OH}) \mathrm{D}$ is a better marker of vitamin $\mathrm{D}$ action than serum $1,25(\mathrm{OH})_{2} \mathrm{D}$ levels (the exception being severe dietary $\mathrm{Ca}$ insufficiency) even though the traditional thinking suggests that vitamin $\mathrm{D}$ acts in an endocrine fashion only after being converted to $1,25(\mathrm{OH})_{2} \mathrm{D}$ in the kidney. Other data indicate that this is possible because extra-renal production of $1,25(\mathrm{OH})_{2} \mathrm{D}$ is a critical component of the protection mediated by high serum $25(\mathrm{OH}) \mathrm{D}$ levels. This puts $1,25(\mathrm{OH})_{2} \mathrm{D}$ in a new role as an autocrine or paracrine mediator rather than an endocrine hormone. In the second part of the review, we examined the evidence that rapid activation of signal-transduction pathways by $1,25(\mathrm{OH})_{2} \mathrm{D}$ constitutes a new, and important mode of vitamin D action apart from the traditional activation of gene transcription mediated through the VDR. With the possibility that a paracrine role exists for $1,25(\mathrm{OH})_{2} \mathrm{D}$, we can begin to make physiological sense of these rapid actions for $1,25(\mathrm{OH})_{2} \mathrm{D}$. It will be interesting to learn whether regional fluxes in $1,25(\mathrm{OH})_{2} \mathrm{D}$ levels due to local production could be occurring and signalling cells, even though serum levels of the hormone do not change. These data, while complicating our model of vitamin D action, provide new life to the study of the nutritional role of vitamin D and stress the importance of high vitamin D status for maximising the protective effects of vitamin D on $\mathrm{Ca}$ homeostasis and for cancer prevention.

\section{References}

Ahonen MH, Tenkanen L, Teppo L, Hakama M \& Tuohimaa P (2000) Prostate cancer risk and prediagnostic serum 25-hydroxyvitamin D levels (Finland). Cancer Causes Control 11, $847-852$.

Armbrecht HJ, Boltz MA, Hodam TL \& Kumar VB (2001) Differential responsiveness of intestinal epithelial cells to $1,25-$ dihydroxyvitamin D3 - role of protein kinase C. Journal of Endocrinology 169, 145-151.

Baran DT, Sorensen AM, Shalhoub V, Owen T, Stein G \& Lian J (1992) The rapid nongenomic actions of 1 alpha,25-dihydroxyvitamin D3 modulate the hormone-induced increments in osteocalcin gene transcription in osteoblast-like cells. Journal of Cellular Biochemistry 50, 124-129.

Barger-Lux MJ, Heaney RP, Lanspa SJ, Healy JC \& DeLuca HF (1995) An investigation of sources of variation in calcium absorption efficiency. Journal of Clinical Endocrinology and Metabolism 80, 406-411.

Barletta F, Freedman LP \& Christakos S (2002) Enhancement of VDR-mediated transcription by phosphorylation: correlation with increased interaction between the VDR and DRIP205, a subunit of the VDR-interacting protein coactivator complex. Molecular Endocrinology 16, 301-314.

Bettoun DJ, Burris TP, Houck KA, Buck DW II, Stayrook KR, Khalifa B, Lu J, Chin WW \& Nagpal S (2003) Retinoid X receptor is a nonsilent major contributor to vitamin $\mathrm{D}$ receptormediated transcriptional activation. Molecular Endocrinology 17, 2320-2328.

Boyan BD, Dean DD, Sylvia VL \& Schwartz Z (1994) Nongenomic regulation of extracellular matrix events by vitamin D metabolites. Journal of Cellular Biochemistry 56, 331-339.

Boyan BD, Dean DD, Sylvia VL \& Schwartz Z (2003) Steroid hormone action in musculoskeletal cells involves membrane receptor and nuclear receptor mechanisms. Connective Tissue Research 44, Suppl. 1, 130-135.

Boyan BD, Sylvia VL, Dean DD, Pedrozo H, Del Toro F, Nemere I, Posner GH \& Schwartz Z (1999) 1,25-(OH)2D3 modulates 
growth plate chondrocytes via membrane receptor-mediated protein kinase $\mathrm{C}$ by a mechanism that involves changes in phospholipid metabolism and the action of arachidonic acid and PGE2. Steroids 64, 129-136.

Bronner F, Pansu D \& Stein WD (1986) An analysis of intestinal calcium transport across the rat intestine. American Journal of Physiology 250, G561-G569.

Brumbaugh PF \& Haussler MR (1973) 1Alpha, 25-dihydroxyvitamin D3 receptor: competitive binding of vitamin D analogs. Life Sciences 13, 1737-1746.

Buitrago C, Boland R \& de Boland AR (2001a) The tyrosine kinase c-Src is required for 1,25(OH)2-vitamin D3 signalling to the nucleus in muscle cells. Biochimica et Biophysica Acta 1541, 179-187.

Buitrago C, Vazquez G, de Boland AR \& Boland R (2001b) The vitamin $\mathrm{D}$ receptor mediates rapid changes in muscle protein tyrosine phosphorylation induced by $1,25(\mathrm{OH})(2) \mathrm{D}(3)$. Biochemical and Biophysical Research Communications 289, $1150-1156$.

Buitrago C, Vazquez G, de Boland AR \& Boland RL (2000) Activation of Src kinase in skeletal muscle cells by $1,1,25-$ $(\mathrm{OH}(2))$-vitamin $\mathrm{D}(3)$ correlates with tyrosine phosphorylation of the vitamin D receptor (VDR) and VDR-Src interaction. Journal of Cellular Biochemistry 79, 274-281.

Chapuy MC, Preziosi P, Maamer M, Arnaud S, Galan P, Hercberg S \& Meunier PJ (1997) Prevalence of vitamin D insufficiency in an adult normal population. Osteoporosis International 7, 439-443.

Chen H, Lin RJ, Xie W, Wilpitz D \& Evans RM (1999) Regulation of hormone-induced histone hyperacetylation and gene activation via acetylation of an acetylase. Cell 98, 675-686.

Chiba N, Suldan Z, Freedman L \& Parvin J (2000) Binding of liganded vitamin $\mathrm{D}$ receptor to the vitamin $\mathrm{D}$ receptor interacting protein coactivator complex induces interaction with RNA polymerase II holoenzyme. Journal of Biological Chemistry 275, 10719-10722.

Dawson-Hughes B, Harris S, Kramich C, Dallal G \& Rasmussen HM (1993) Calcium retention and hormone levels in black and white women on high- and low-calcium diets. Journal of Bone and Mineral Research 8, 779-787.

Demay MB, Kiernan MS, DeLuca HF \& Kronenberg HM (1992) Sequences in the human parathyroid hormone gene that bind the 1,25-dihydroxyvitamin D3 receptor and mediate transcriptional repression in response to 1,25-dihydroxyvitamin D3. Proceedings of the National Academy of Sciences USA 89, 8097-8101.

Desai RK, van Wijnen AJ, Stein JL, Stein GL \& Lian JB (1995) Control of 1,25-dihydroxyvitamin D3 receptor-mediated enhancement of osteoclacin gene transcription: effects of perturbing phosphorylation pathways by okadaic acid and staurosporine. Endocrinology 136, 5685-5693.

Devine A, Wilson SG, Dick IM \& Prince RL (2002) Effects of vitamin D metabolites on intestinal calcium absorption and bone turnover in elderly women. American Journal of Clinical Nutrition 75, 283-288.

Dusso A, Lopez-Hilker S, Rapp N \& Slatopolsky E (1988) Extrarenal production of calcitriol in chronic renal failure. Kidney International 34, 368-375.

Dwivedi PP, Hii CS, Ferrante A, Tan J, Der CJ, Omdahl JL, Morris HA \& May BK (2002) Role of MAP kinases in the 1,25dihydroxyvitamin D3-induced transactivation of the rat cytochrome P450C24 (CYP24) promoter. Specific functions for ERK1/ERK2 and ERK5. Journal of Biological Chemistry 277, 29643-29653.

Erben RG, Soegiarto DW, Weber K, Zeitz U, Lieberherr M, Gniadecki R, Moller G, Adamski J \& Balling R (2002) Deletion of deoxyribonucleic acid binding domain of the vitamin $\mathrm{D}$ receptor abrogates genomic and nongenomic functions of vitamin D. Molecular Endocrinology 16, 1524-1537.

Farach-Carson MC \& Nemere I (2003) Membrane receptors for vitamin D steroid hormones: potential new drug targets. Current Drug Targets 4, 67-76.

Freedman LP (1999) Increasing the complexity of coactivation in nuclear receptor signaling. Cell 97, 5-8.

Glorieux FH \& St-Arnaud R (1997) Vitamin D Pseudodeficiency. In Vitamin D, pp. 755-764 [DD Feldman, FH Gloriex and JW Pike, editors]. San Diego, CA: Academic Press.

Haddad JG Jr \& Rojanasathit S (1976) Acute administration of 25-hydroxycholecalciferol in man. Journal of Clinical Endocrinology and Metabolism 42, 284-290.

Hanchette CL \& Schwartz GG (1992) Geographic patterns of prostate cancer mortality. Evidence for a protective effect of ultraviolet radiation. Cancer 70, 2861-2869.

Hara H, Yasunami Y \& Adachi T (2002) Alteration of cellular phosphorylation state affects vitamin $\mathrm{D}$ receptor-mediated CYP3A4 mRNA induction in Caco-2 cells. Biochemical and Biophysical Research Communications 296, 182-188.

Harvey BJ, Alzamora R, Healy V, Renard C \& Doolan CM (2002) Rapid responses to steroid hormones: from frog skin to human colon. A homage to Hans Ussing. Biochimica et Biophysica Acta 1566, 116-128.

Haussler MR, Whitfield GK, Haussler CA, Hsieh JC, Thompson PD, Selznick SH, Dominguez CE \& Jurutka PW (1998) The nuclear vitamin D receptor: biological and molecular regulatory properties revealed. Journal of Bone and Mineral Research 13 , 325-349.

Heaney RP, Barger-Lux MJ, Dowell MS, Chen TC \& Holick MF (1997) Calcium absorptive effects of vitamin D and its major metabolites. Journal of Clinical Endocrinology and Metabolism 82, 4111-4116.

Heaney RP, Dowell MS, Hale CA \& Bendich A (2003) Calcium absorption varies within the reference range for serum 25hydroxyvitamin D. Journal of the American College of Nutrition 22, 142-146.

Hedlund TE, Moffatt KA \& Miller GJ (1996a) Stable expression of the nuclear vitamin $\mathrm{D}$ receptor in the human prostatic carcinoma cell line JCA-1: evidence that the antiproliferative effects of 1 alpha, 25-dihydroxyvitamin D3 are mediated exclusively through the genomic signaling pathway. Endocrinology 137 , 1554-1561.

Hedlund TE, Moffatt KA \& Miller GJ (1996b) Vitamin D receptor expression is required for growth modulation by 1 alpha,25dihydroxyvitamin D3 in the human prostatic carcinoma cell line ALVA-31. Journal of Steroid Biochemistry and Molecular Biology 58, 277-288.

Holick M (1997) Photobiology of vitamin D. In Vitamin D, pp. 33-39 [D Feldman, F Glorieux and J Pike, editors]. San Diego, CA: Academic Press.

Holick MF (2003) Vitamin D: A millennium perspective. Journal of Cellular Biochemistry 88, 296-307.

Hsu JY, Feldman D, McNeal JE \& Peehl DM (2001) Reduced 1alpha-hydroxylase activity in human prostate cancer cells correlates with decreased susceptibility to 25-hydroxyvitamin D3induced growth inhibition. Cancer Research 61, 2852-2856.

Jongen MJ, van der Vijgh WJ, Lips P \& Netelenbos JC (1984) Measurement of vitamin D metabolites in anephric subjects. Nephron 36, 230-234.

Koyama H, Inaba M, Nishizawa Y, Ohno S \& Morii H (1994) Protein kinase $\mathrm{C}$ is involved in 24-hydroxylase gene expression induced by $1,25(\mathrm{OH})_{2} \mathrm{D}_{3}$ in rat intestinal epithelial cells. Journal of Cellular Biochemistry 55, 230-240.

Lee KC, Li J, Cole PA, Wong J \& Kraus WL (2003) Transcriptional activation by thyroid hormone receptor-beta involves chromatin remodeling, histone acetylation, and syner- 
gistic stimulation by $\mathrm{p} 300$ and steroid receptor coactivators. Molecular Endocrinology 17, 908-922.

MacLaughlin JA, Anderson RR \& Holick MF (1982) Spectral character of sunlight modulates photosynthesis of previtamin D3 and its photoisomers in human skin. Science 216, 1001-1003.

Mason RS, Lissner D, Posen S \& Norman AW (1980) Blood concentrations of dihydroxylated vitamin $\mathrm{D}$ metabolites after an oral dose. British Medical Journal 280, 449-450.

Miller GJ, Stapleton GE, Hedlund TE \& Moffat KA (1995) Vitamin D receptor expression, 24-hydroxylase activity, and inhibition of growth by 1 alpha, 25-dihydroxyvitamin D3 in seven human prostatic carcinoma cell lines. Clinical Cancer Research 1,997-1003.

Nemere I \& Farach-Carson MC (1998) Membrane receptors for steroid hormones: a case for specific cell surface binding sites for vitamin D metabolites and estrogens. Biochemical and Biophysical Research Communications 248, 443-449.

Paredes R, Gutierrez J, Gutierrez S, Allison L, Puchi M, Imschenetzky M, van Wijnen A, Lian J, Stein G, Stein J \& Montecino M (2002) Interaction of the 1alpha,25-dihydroxyvitamin D3 receptor at the distal promoter region of the bone-specific osteocalcin gene requires nucleosomal remodelling. Biochemical Journal 363, 667-676.

Rachez C, Lemon BD, Suldan Z, Bromleigh V, Gamble M, Naar AM, Erdjument-Bromage H, Tempst P \& Freedman LP (1999) Ligand-dependent transcription activation by nuclear receptors requires the DRIP complex. Nature 398, 824-828.

Rowan BG, Weigel NL \& O'Malley BW (2000) Phosphorylation of steroid receptor coactivator-1. Identification of the phosphorylation sites and phosphorylation through the mitogen-activated protein kinase pathway. Journal of Biological Chemistry 275, 4475-4483.

Schwartz GG \& Hulka BS (1990) Is vitamin D deficiency a risk factor for prostate cancer? (hypothesis). Anticancer Research 10, 1307-1311.

Schwartz Z, Brooks B, Swain L, Deltoro F, Norman A \& Boyan B (1992) Production of 1,25-dihydroxyvitamin-D3 and 24,25dihydroxyvitamin-D3 by growth zone and resting zone chondrocytes is dependent on cell maturation and is regulated by hormones and growth factors. Endocrinology 130, 2495-2504.

Sitrin MD, Bissonnette M, Bolt MJ, Wali R, Khare S, ScaglioneSewell B, Skarosi S \& Brasitus TA (1999) Rapid effects of $1,25(\mathrm{OH}) 2$ vitamin D3 on signal transduction systems in colonic cells. Steroids 64, 137-142.

Song Y, Kato S \& Fleet JC (2003a) Vitamin D receptor (VDR) knockout mice reveal VDR-independent regulation of intestinal calcium absorption and $\mathrm{ECaC} 2$ and calbindin $\mathrm{D}(9 \mathrm{k})$ mRNA. Journal of Nutrition 133, 374-380.

Song Y, Peng X, Porta A, Takanaga H, Peng JB, Hediger MA, Fleet JC \& Christakos S (2003b) Calcium transporter 1 and epithelial calcium channel messenger ribonucleic acid are differentially regulated by 1,25 dihydroxyvitamin D3 in the intestine and kidney of mice. Endocrinology 144, 3885-3894.

St Arnaud R, Dardenne O, Prud'homme J, Hacking SA \& Glorieux FH (2003) Conventional and tissue-specific inactivation of the 25-hydroxyvitamin D-1alpha-hydroxylase (CYP27B1). Journal of Cellular Biochemistry 88, 245-251.

Thomas MK, Lloyd-Jones DM, Thadhani RI, Shaw AC, Deraska DJ, Kitch BT, Vamvakas EC, Dick IM, Prince RL \& Finkelstein JS (1998) Hypovitaminosis D in medical inpatients. New England Journal of Medicine 338, 777-783.

Trivedi DP, Doll R \& Khaw KT (2003) Effect of four monthly oral vitamin D3 (cholecalciferol) supplementation on fractures and mortality in men and women living in the community: randomised double blind controlled trial. British Medical Journal 326, 469.

van Cromphaut SJ, Dewerchin M, Hoenderop JG, Stockmans I, Van Herck E, Kato S, Bindels RJ, Collen D, Carmeliet P, Bouillon R \& Carmeliet G (2001) Duodenal calcium absorption in vitamin D receptor-knockout mice: functional and molecular aspects. Proceedings of the National Academy of Sciences USA 98, 13324-13329.

Wali RK, Kong J, Sitrin MD, Bissonnette M \& Li YC (2003) Vitamin D receptor is not required for the rapid actions of 1,25dihydroxyvitamin D3 to increase intracellular calcium and activate protein kinase $\mathrm{C}$ in mouse osteoblasts. Journal of Cellular Biochemistry 88, 794-801.

Whitlatch LW, Young MV, Schwartz GG, Flanagan JN, Burnstein KL, Lokeshwar BL, Rich ES, Holick MF \& Chen TC (2002) 25-Hydroxyvitamin D-1alpha-hydroxylase activity is diminished in human prostate cancer cells and is enhanced by gene transfer. Journal of Steroid Biochemistry and Molecular Biology 81, 135-140.

Zehnder D, Bland R, Williams MC, McNinch RW, Howie AJ, Stewart PM \& Hewison M (2001) Extrarenal expression of 25hydroxyvitamin d(3)-1 alpha-hydroxylase. Journal of Clinical Endocrinology and Metabolism 86, 888-894.

Zhuang SH, Schwartz GG, Cameron D \& Burnstein KL (1997) Vitamin D receptor content and transcriptional activity do not fully predict antiproliferative effects of vitamin D in human prostate cancer cell lines. Molecular and Cellular Endocrinology 126, 83-90. 